\title{
Estimating some demographic parameters of Aphidius matricariae Haliday (Hymenoptera: Braconidae), the parasitoid of the greenbug aphid, Schizaphis graminum (Rondani) (Hemiptera: Aphididae), at different temperatures
}

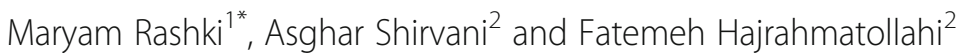

\begin{abstract}
Some demographic parameters of the indigenous parasitoid, Aphidius matricariae Haliday (Hymenoptera: Braconidae) parasitizing the greenbug, Schizaphis graminum (Rondani) (Hemiptera: Aphididae), were estimated at 3 different temperatures $\left(20,25\right.$, and $\left.30 \pm 1{ }^{\circ} \mathrm{C} ; 70 \pm 5 \% \mathrm{RH} ; 16 \mathrm{~L}: 8 \mathrm{D}\right)$. According to age-specific theory, the demographic parameters of the parasitoid were computed by related formulas. The results showed that duration of mummy's formation to adult emergence and oviposition to adult emergence were significantly prolonged at $30^{\circ} \mathrm{C}$. The high temperature $\left(30^{\circ} \mathrm{C}\right)$ markedly shortened the longevity and lifespan of the wasp. The lowest value of fecundity $(6.35 \pm$ 0.85) significantly occurred when the female wasps were exposed to $30^{\circ} \mathrm{C}$. The estimated values of $r_{m}$ were remarkably high when the female wasps were exposed to $20(0.320 \pm 0.011)$ and $25^{\circ} \mathrm{C}(0.310 \pm 0.009)$. The lowest and highest values of the $R_{0}$ significantly occurred at $30(6.167 \pm 0.754)$ and $20^{\circ} \mathrm{C}(55.306 \pm 6.316)$. The $\lambda, T, D T$, and $r_{w}$ values were noticeably decreased at high temperature, and there was non-significant difference between the two other temperatures. High temperature decreased the number of females produced per female per day $(m x)$ and survival rate $(I x)$ of the parasitoid wasp. The highest $m x$ and $I x$ happened at 20 and $25^{\circ} \mathrm{C}$, respectively. Therefore, the results showed that the parasitoid wasp was sensitive to the high temperature, as its low reproduction, survival, and short adult longevity were recorded. Considering the characteristics, the wasp appeared to be well-adapt with the temperatures below $30^{\circ} \mathrm{C}$. Understanding the optimal temperatures for the life history traits of $A$. matricariae could promote the performance of the parasitoid wasp in different climatic regions, and this might advance the mass production of the parasitoid applied in IPM program for successful biological control of S. graminum.
\end{abstract}

Keywords: Aphidius matricariae, Fecundity, Life table, Longevity, Schizaphis graminum, Temperature

\footnotetext{
*Correspondence: ma_rashkigh@yahoo.com

'Department of Biodiversity, Institute of Science and High Technology and Environmental Sciences, Graduate University of Advanced Technology,

Kerman, Iran

Full list of author information is available at the end of the article
}

\section{Springer Open}

(ㅇ The Author(s). 2020 Open Access This article is licensed under a Creative Commons Attribution 4.0 International License, which permits use, sharing, adaptation, distribution and reproduction in any medium or format, as long as you give appropriate credit to the original author(s) and the source, provide a link to the Creative Commons licence, and indicate if changes were made. The images or other third party material in this article are included in the article's Creative Commons licence, unless indicated otherwise in a credit line to the material. If material is not included in the article's Creative Commons licence and your intended use is not permitted by statutory regulation or exceeds the permitted use, you will need to obtain permission directly from the copyright holder. To view a copy of this licence, visit http://creativecommons.org/licenses/by/4.0/. 


\section{Background}

The braconid wasps are important parasitoids in controlling aphids (Jones et al., 2003). Accordingly, one of the most efficient member of the family is a proovigenic and koinobiont parasitoid, Aphidius matricariae Haliday (Hymenoptera: Braconidae), which is used as a successful biological control agent to suppress several aphid pest populations (Boivin et al., 2012). Most studies have investigated the role of $A$. matricariae to control aphid pests in orchards and vegetables (Zamani et al., 2007 and Wick 2009). However, there are several evidences showing the performance of the parasitoid wasp as a biocontrol agent of cereal aphid species such as Diuraphis noxia (Mordvilko) (De Farias and Hopper, 1999) and Schizaphis graminum (Rondani) (Mustață and Mustață, 2009).

The greenbug, Schizaphis graminum (Rondani) (Hemiptera: Aphididae), is an important aphid pest of cereal crops that causes enormous losses via direct (e.g., sap suction, germination decrease, and other phytotoxic impacts) and indirect damage (virus transmission like barley yellow dwarf luteovirus) (Costa et al., 2010). Use of the indigenous parasitoid, A. matricariae, can be considered as an alternative and safe way to suppress the greenbug invasion instead of insecticide application. However, some abiotic variables affect the wasp ability in parasitizing the aphid hosts and its fitness (El-Heneidy et al., 2003). As insects are poikilotherms, temperature is a critical abiotic factor during their life cycle, and any thermal fluctuation can affect their biological properties such as their growth and reproduction (Wang et al., 2009).

Parasitism of A. colemani Viereck (Hymenoptera: Braconidae) to the bird cherry-oat aphid, Rhopalosiphum padi (L.), was tested at different temperatures, and it was found that 20 and $25^{\circ} \mathrm{C}$ were the preferred thermal condition (Goh et al., 2001). Liu and Tsai (2002) exhibited that the maximum population growth of Lysiphlebia mirzai Shuja-Uddin, the braconid parasitoid of the brown citrus aphid, Toxoptera citricida (Kirkaldy), occurred at a temperature range of $15-25^{\circ} \mathrm{C}$. Likewise, parasitism rate and biological characteristics of the aphelinid parasitoid wasp, Aphelinus asychis Walker, were negatively influenced by the unfavorable high temperatures (Wang et al., 2016).

Some biological and life table parameters of the parasitoid, Aphelinus varipes (Forster), were investigated under a range of temperature (Yashima and Murai, 2013). The results manifested that the increased temperature had detrimental effects on the wasp developmental period, emergence rate, and sex ratio. Moreover, the intrinsic rate of increase $\left(r_{m}\right)$ and net reproductive rate $\left(R_{0}\right)$ values were higher at 25 than $20^{\circ} \mathrm{C}$ (Yashima and Murai, 2013). In addition to the crucial effects of thermal changes on insects, it would be worthwhile having knowledge on demographic parameters of insects like life table parameters (Maia et al., 2000).

Therefore, the aim of the present research was to determine the impacts of different temperatures on some life table parameters of the Iranian native population of A. matricariae when parasitizing the greenbug, S. graminum under laboratory conditions.

\section{Materials and methods \\ Plant and insect sources}

For rearing the greenbug, S. graminum, and conducting the experiments, a native wheat cultivar, named Alvand, was planted in pots (12-cm high and $15-\mathrm{cm}$ diameters) under greenhouse conditions. The colony of the greenbug was initiated by adults collected from gramineous plants in Kerman (Kerman province, Iran) in a control environment chamber at $25 \pm 1{ }^{\circ} \mathrm{C}, 70 \pm 5 \% \mathrm{RH}$, and a photoperiod of $16 \mathrm{~L}: 8 \mathrm{D}$. The $3 \mathrm{rd}$ instar nymphs were used in all tests.

The indigenous parasitoid wasps, A. matricariae, were gained from the mummies of greenbug collected from gramineous plants in Kerman (Kerman province, Iran). After the wasp identification, the parasitoids were reared in a Plexiglas cage $(50 \times 50 \times 60 \mathrm{~cm})$, using S. graminum on potted wheat plants in the control environment chamber. The parasitoid wasps were provided by $60 \%$ honey solution. In the present study, 1-day-old mated female wasps from one generation were applied.

\section{Effect of different temperatures on biological characteristics of $A$. matricariae}

To test the effects of 3 different constant temperatures including 20,25 , and $30^{\circ} \mathrm{C}$ on some demographic parameters of $A$. matricariae, an experimental unit was designed $(70 \pm 5 \% \mathrm{RH}, 16 \mathrm{~L}: 8 \mathrm{D})$. Hence, the cut wheat leaves were laid onto $2 \%$ water-agar in a Petri dish (9$\mathrm{cm}$ diameter) with perforated lid. Then, the hole was covered with a piece of thin mesh (2-cm diameter), and after that, 30 3rd instar nymphs of the greenbug were placed in the experimental unit as well as a 1-day-old mated female of the parasitoid. Each treatment was repeated 20 times (20 replicates for each temperature). The developmental times including mummification to adult emergence and oviposition to adult emergence were recorded.

After adult emergences, each 1-day-old mated female wasp was daily provided by 30 new 3rd instar nymphs of the greenbug until death, and the nymphs were then kept for mummy formations. Subsequently, longevity, lifespan, fecundity, and life table parameters were calculated. 
Table 1 Development time (mean \pm SE) of Aphidius matricariae parasitizing Schizaphis graminum at various temperatures

\begin{tabular}{|c|c|c|c|c|c|c|}
\hline \multirow{2}{*}{$\begin{array}{l}\text { Temperature } \\
\left({ }^{\circ} \mathrm{C}\right)\end{array}$} & \multicolumn{3}{|c|}{ Mummy formation to adult emergence (day) } & \multicolumn{3}{|c|}{ Oviposition to adult emergence (day) } \\
\hline & q & 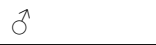 & $\hat{o}+q$ & q & $\delta^{\pi}$ & $\hat{o}+q$ \\
\hline 20 & $4.90 \pm 0.17^{b}$ & $4.80 \pm 0.18^{b}$ & $4.90 \pm 0.12^{b}$ & $8.80 \pm 0.17^{b}$ & $8.90 \pm 0.16^{b}$ & $8.90 \pm 0.11^{b}$ \\
\hline 25 & $4.90 \pm 0.15^{b}$ & $4.90 \pm 0.12^{b}$ & $4.90 \pm 0.16^{b}$ & $8.70 \pm 0.17^{b}$ & $8.90 \pm 0.14^{b}$ & $8.80 \pm 0.11^{b}$ \\
\hline 30 & $5.40 \pm 0.17^{\mathrm{a}}$ & $6.20 \pm 0.23^{\mathrm{a}}$ & $5.80 \pm 0.17^{\mathrm{a}}$ & $10.25 \pm 0.17^{\mathrm{a}}$ & $10.75 \pm 0.25^{a}$ & $10.50 \pm 0.18^{\mathrm{a}}$ \\
\hline
\end{tabular}

Means followed by different letter in the same column are significantly different (Tukey's test, $P<0.05$ )

\section{Statistical analysis}

In terms of the Carey (1993) (age-specific theory), the demographic parameters were computed by the following formulas:

$$
\begin{aligned}
& R_{0}=\sum l_{x} m_{x} \\
& \sum l_{x} m_{x} e^{-r x}=1 \\
& D T=\operatorname{Ln}(2) / r \\
& \lambda=e^{r} \\
& \mathrm{~T}=\frac{\ln \left(\mathrm{R}_{0}\right)}{\mathrm{r}} \\
& r_{w}=\left(e^{f}\right)^{7}
\end{aligned}
$$

where the $m x$ and $l x$ are the numbers of females produced per female per day and survival rate of the parasitoid wasp, respectively; $r_{m}$ and $R_{0}$ are the intrinsic rate of increase and net reproductive rate, respectively; $r_{w}$ and $\lambda$ are the increase rate in one week and finite rate of increase, respectively; and $T$ and $D T$ are mean generation and doubling times. The data were subjected to analysis of variance (ANOVA), and the averages were compared by Tukey's test at the 0.05 level. The Statistical Analysis System (SAS Institute, 1989) was applied for the calculations.

\section{Results and discussion}

The developmental time of the parasitoid wasp, $A$. matricariae, parasitizing the greenbug, S. graminum, including mummy formation to adult emergence and oviposition to adult emergence was calculated at different temperatures. The results showed that there was nonsignificant difference between 20 and $25^{\circ} \mathrm{C}$ (Table 1). However, duration of mummy formation until adult emergence $\left(F_{2,119}=18.57, P<0.05\right)$ and oviposition until adult emergence $\left(F_{2,119}=16.94, P<0.05\right)$ were significantly prolonged at $30{ }^{\circ} \mathrm{C}$. There was nonsignificant difference between males and females in the above-mentioned biological properties.

The thermal alteration, as an abiotic factor, could affect the biological characteristics of the biocontrol agents as well as their insect hosts (Wang et al., 2014). Similarly, the present study revealed that the developmental time of $A$. matricariae, parasitizing the greenbug, $S$. graminum, was influenced by changing the temperature. Therefore, the high temperature $\left(30^{\circ} \mathrm{C}\right)$ prolonged the mummy formation to adult emergence and oviposition to adult emergence.

In contrast, the developmental time of the aphelinid endoparasitoid, Aphelinus asychis Walker, parasitizing the cotton aphid, Aphis gossypii Glover, decreased when the constant temperature was elevated from 15 to $32.5^{\circ} \mathrm{C}$ (Schirmer et al., 2008 and Byeon et al., 2011) as well as the parasitoid $A$. varipes (Yashima and Murai 2013) and A. matricariae parasitizing Nasonovia ribisnigri (Mosely) (Farsi et al., 2019) and R. padi (El-Heneidy et al., 2003). The difference might be resulted from the difference between the parasitoid species and/or host aphids. In consistent with the obtained results, there were non-significant differences in total developmental time of $A$. varipes at 20 and $25^{\circ} \mathrm{C}$ when parasitized $3 \mathrm{rd}$

\begin{tabular}{|c|c|c|c|c|c|c|c|}
\hline \multirow{2}{*}{$\begin{array}{l}\text { Temperatures } \\
\left({ }^{\circ} \mathrm{C}\right)\end{array}$} & \multicolumn{3}{|c|}{ Longevity (day) } & \multicolumn{3}{|l|}{ Lifespan (day) } & \multirow[t]{2}{*}{ Fecundity } \\
\hline & q & $\hat{\sigma}$ & $\hat{0}+q$ & q & $\pi$ & $\hat{0}+q$ & \\
\hline 20 & $7.15 \pm 0.63^{a}$ & $6.20 \pm 0.47^{a}$ & $6.67 \pm 0.42^{\mathrm{a}}$ & $16.05 \pm 0.58^{\mathrm{a}}$ & $15.10 \pm 0.48^{\mathrm{a}}$ & $15.07 \pm 0.40^{a}$ & $51.10 \pm 7.07^{\mathrm{a}}$ \\
\hline 25 & $7.80 \pm 0.87^{\mathrm{a}}$ & $6.40 \pm 0.60^{a}$ & $7.10 \pm 0.57^{\mathrm{a}}$ & $16.90 \pm 0.88^{\mathrm{a}}$ & $15.75 \pm 0.58^{\mathrm{a}}$ & $16.32 \pm 0.58^{\mathrm{a}}$ & $46.90 \pm 0.93^{a}$ \\
\hline 30 & $3.30 \pm 0.35^{b}$ & $2.35 \pm 0.22^{b}$ & $2.82 \pm 0.25^{b}$ & $13.30 \pm 0.30^{b}$ & $12.60 \pm 0.32^{b}$ & $12.95 \pm 0.22^{b}$ & $6.35 \pm 0.85^{b}$ \\
\hline
\end{tabular}
nymphal instar of $A$. gossypii (Rohne 2002). Zamani et al. (2007) reported that $A$. matricariae had its maximum development at $25^{\circ} \mathrm{C}$, and the total developmental

Table 2 Influence of various temperatures on adult longevity, lifespan, and fecundity of Aphidius matricariae parasitizing Schizaphis graminum

Means followed by different letter in the same column are significantly different (Tukey's test, $P<0.05$ ) 
Table 3 Life table parameters (mean \pm SE) of Aphidius matricariae parasitizing Schizaphis graminum at various temperatures

\begin{tabular}{|c|c|c|c|}
\hline \multirow[t]{2}{*}{ Parameters } & \multicolumn{3}{|l|}{ Temperature $\left({ }^{\circ} \mathrm{C}\right)$} \\
\hline & 20 & 25 & 30 \\
\hline$\overline{r_{m}(\text { \& } / \text { / } / \text { day })}$ & $0.320 \pm 0.011^{\mathrm{a}}$ & $0.310 \pm 0.009^{\mathrm{a}}$ & $0.160 \pm 0.014^{b}$ \\
\hline$R_{0}$ (q/P/generation) & $55.306 \pm 6.316^{a}$ & $48.890 \pm 5.148^{b}$ & $6.167 \pm 0.754^{c}$ \\
\hline$\lambda\left(\right.$ day $\left.^{-1}\right)$ & $1.382 \pm 0.014^{\mathrm{a}}$ & $1.362 \pm 0.013^{\mathrm{a}}$ & $1.171 \pm 0.017^{b}$ \\
\hline$T$ (day) & $14.530 \pm 0.306^{\mathrm{a}}$ & $15.655 \pm 0.172^{a}$ & $10.780 \pm 0.160^{b}$ \\
\hline$D T$ (day) & $2.155 \pm 0.067^{\mathrm{a}}$ & $2.235 \pm 0.069^{a}$ & $4.281 \pm 0.342^{b}$ \\
\hline$r_{w}$ (q/q/week) & $9.660 \pm 0.096^{a}$ & $9.536 \pm 0.091^{a}$ & $8.216 \pm 0.117^{b}$ \\
\hline
\end{tabular}

Means followed by different letter in the same row are significantly different (Tukey's test, $P<0.05$ )

$r_{m}$ intrinsic rate of increase, $R_{0}$ net reproductive rate, $\lambda$ finite rate of increase, $T$ mean generation time, $D T$ doubling time, $r_{w}$ increase rate in 1 week

times of the parasitoid wasp parasitizing the aphid hosts including A. gossypii and Myzus persicae (Sulzer) were higher than that obtained in the present study.

In the present study, the high temperature $\left(30^{\circ} \mathrm{C}\right)$ decreased the lifespan of $A$. matricariae, due to higher metabolic rate (Brown et al., 2004). Moreover, there was non-significant difference between males and females of the parasitoid wasp in different developmental durations, which was in consistent with the outcome of Liu and Tsai (2002).

As shown in Table 2, the high temperature $\left(30{ }^{\circ} \mathrm{C}\right)$ significantly affected the lifetime of $A$. matricariae adults parasitizing $S$. graminum by decreasing their longevity $\left(F_{2,119}=23.19, P<0.05\right)$ and lifespan $\left(F_{2,119}=22.85, P\right.$ $<0.05)$. In contrast, Bernal and Gonzalez (1997) reported non-significant differences between males and females at each temperature. Similar to the lifetime of the parasitoid, the fecundity did not differ at 20 and $25^{\circ} \mathrm{C}$. However, the lowest value of fecundity differently occurred when the female wasps were exposed to $30{ }^{\circ} \mathrm{C}$ $\left(F_{2,59}=21.18, P<0.05\right)$.

In the present study, the longevity and lifespan of the wasps decreased at the high temperature. Similarly, Wang et al. (2016) demonstrated that the increased temperature decreased the longevity of $A$. asychis parasitizing M. persicae. As well, Schirmer et al. (2008) and Farsi et al. (2019) confirmed the same for A. matricariae parasitizing $N$. ribisnigri. Also, the adult longevity of the aphidiid, Lysiphlebia mirzai Shuja-Uddin, a parasitoid of Toxoptera citricida (Kirkaldy), was reduced by increasing the temperature (Liu and Tsai, 2002) similar to the longevity of Diaeretiella rapae (M'Intosh) attacking $D$. noxia (Bernal and Gonzalez, 1997).

Similarly, Wang et al. (2016) and Farsi et al. (2019) confirmed the obtained results that the high temperature had adverse effect on the fecundity of $A$. matricariae. Accordingly, the females had short longevities at high temperatures. However, there were non-significant differences between 20 and $25^{\circ} \mathrm{C}$ in longevity and fecundity of $A$. matricariae which is in accordance with the results of Yashima and Murai (2013). Besides, Liu and Tsai (2002) reported that the female wasps of L. mirzai were able to lay high and low eggs at 25 and $32{ }^{\circ} \mathrm{C}$, respectively. However, Rohne (2002) explained that different constant temperatures had no considerable effect on the mummies produced by the female parasitoid, $A$. varipes as well as the fecundity of $D$. rapae parasitizing $D$. noxia (Bernal and Gonzalez, 1997).

All life table parameters of $A$. matricariae parasitizing the greenbug, S. graminum, were affected by the tested temperatures (Table 3). The intrinsic rate of increase $\left(r_{m}\right)$ values had significant difference at $30^{\circ} \mathrm{C}$ among the 3 tested temperatures, and the high temperature resulted in decreasing the parameter $\left(F_{2,62}=62.80, P<0.05\right)$.

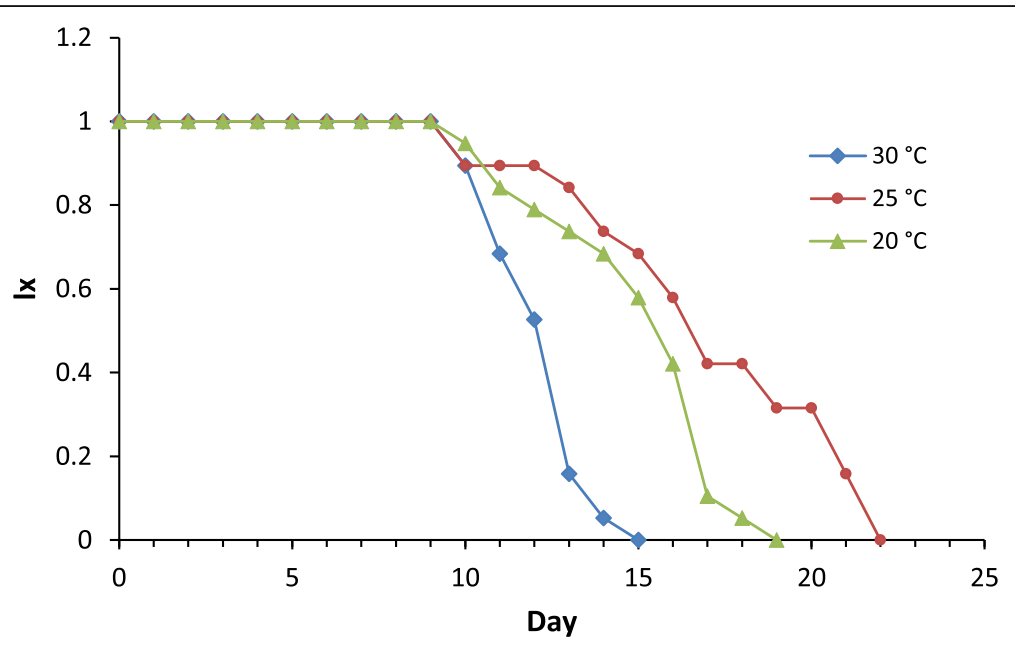

Fig. 1 Survival rate $(I x)$ of Aphidius matricariae parasitizing Schizaphis graminum at various temperatures 


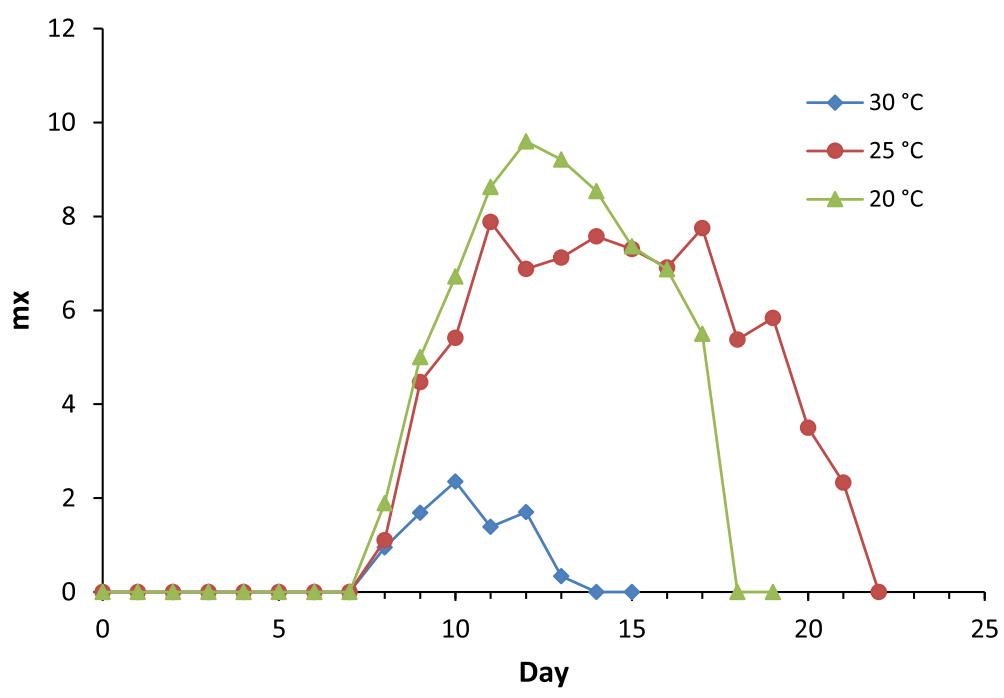

Fig. 2 Number of females produced/female/day $(m x)$ by Aphidius matricariae parasitizing Schizaphis graminum at various temperatures

The estimated values of $r_{m}$ were remarkably higher, when the female wasps of $A$. matricariae were exposed to 20 and $25^{\circ} \mathrm{C}$. Also, a significant difference was observed in the net reproductive rate $\left(R_{0}\right)$ value $\left(F_{2,54}=\right.$ 33.72, $P<0.05$ ) among the treatments (Table 3$)$. The lowest and highest values of the $R_{O}$ were significantly occurred at 30 and $20^{\circ} \mathrm{C}$.

In addition, other life table parameters of $A$. matricariae including finite rate of increase $(\lambda)\left(F_{2,62}=64.24, P\right.$ $<0.05)$, mean generation time $(T)\left(F_{2,} 62=15.43, P<\right.$ $0.05)$, doubling time $(D T)\left(F_{2,62}=34.45, P<0.05\right)$, and increase rate in 1 week $\left(r_{w}\right)\left(F_{2,62}=61.43, P<0.05\right)$ were affected by different temperatures. The results elucidated that the $\lambda, T, D T$, and $r_{w}$ values noticeably decreased at the high temperature $\left(30^{\circ} \mathrm{C}\right)$, and there was non-significant difference between the 2 other temperatures $\left(20\right.$ and $\left.25^{\circ} \mathrm{C}\right)$.

Results of the present study demonstrated that all the life table parameters (e.g., $r_{m}$, and $T$ ) of $A$. matricariae, except $R_{O}$, had non-significant differences at 20 than $25^{\circ} \mathrm{C}$, which agree with the results of Farsi et al. (2019). However, in the present research, the $r_{m}$ value was higher than the values reported by Farsi et al. (2019) for A. matricariae parasitizing N. ribisnigri, and by Shahrokhi et al. (2004) for A. matricariae parasitizing S. graminum. It was indicated that the greenbug was the more suitable host for the parasitoid rather than the lettuce aphid, and also, the indigenous parasitoid population used in the present study was more efficient to control $S$. graminum. Moreover, the $r_{m}$ values for $A$. matricariae parasitizing the peach aphid (Shijko 1989) and the Russian wheat aphid (Reed et al. 1992) were lower than that of data obtained at $20^{\circ} \mathrm{C}$. Nevertheless, Tahriri Adabi et al. (2010) reported that the $r_{m}$ value of $A$. matricariae parasitizing Aphis fabae Scopoli was 0.41 at $25^{\circ} \mathrm{C}$.

Accordingly, in contrast with the $r_{m}$ and $T$ values of the parasitoid, A. varipes was noticeably altered at $25^{\circ} \mathrm{C}$ than at $20^{\circ} \mathrm{C}$, and the increased temperature resulted in decreasing the mean generation time and the elevated intrinsic rate of natural increase (Yashima and Murai 2013).

Denis et al. (2011) found that increasing the temperature negatively affected the foraging efficiency of parasitoids and consequently declining their reproduction. This was supported by the present research that the high temperature $\left(30^{\circ} \mathrm{C}\right)$ had detrimental effects on the life table parameters of $A$. matricariae. Accordingly, the findings were similar to those reported by Giri et al. (1982) who stated that $A$. matricariae efficiently parasitized $M$. persicae at $21^{\circ} \mathrm{C}$. However, the parasitism rate could be increased along with temperature (ambient $+2.0^{\circ} \mathrm{C}$ ) (Bezemer et al. 1998).

Figures 1 and 2 clarified that survival rate of the parasitoid wasp $(l x)$ and the number of females' produced/female/day $(m x)$ were differentially altered at different temperatures. Hence, the high temperature $\left(30^{\circ} \mathrm{C}\right)$ led to decrease the $l x$ and $m x$. In regard with that, the highest $m x$ and $l x$ happened at 20 and $25^{\circ} \mathrm{C}$, respectively.

Likewise, the survival rate of $A$. matricariae was markedly affected by the high temperature $\left(30^{\circ} \mathrm{C}\right)$ and then decreased; as it was reported by Zamani et al. 2007). Several factors might be involved in this decrease. For instance, the synchronization between development of parasitoid and its host could be altered by temperature and could result in their mortality (Mustață and Mustață, 2009). In addition, high temperature might induce the immune system of the parasitoid host to be effective 
(Zufelato et al., 2004). Denis et al. (2011) proposed that thermal increasing resulted in declining the fitness of pro-ovigenic parasitoids. Similarly, the developmental rate of $A$. matricariae parasitizing $D$. noxia decreased at the temperature above $26^{\circ} \mathrm{C}$, and all parasitoid wasps died at $31^{\circ} \mathrm{C}$ (Miller and Gerth 1994).

\section{Conclusion}

Considering the characteristics, the parasitoid wasp $A$. matricariae parasitizing the greenbug, S. graminum, appeared to be well-adapted with the temperatures below $30^{\circ} \mathrm{C}$. Understanding the optimal temperatures for the life history traits of the parasitoid could promote its performance in different climatic zones for the greenbug population suppression which this may advance the mass production of the parasitoid required to be applied in IPM program for successful biological control of $S$. graminum.

\section{Acknowledgements}

Not applicable.

\section{Availability of data and material}

The datasets used and/or analyzed during the current study are available from the corresponding author on reasonable request.

\section{Authors' contributions}

MR created the research plan and wrote the paper. AS analyzed the data and $\mathrm{FH}$ performed the experiments. All authors read and approved the final manuscript.

\section{Funding}

This work was funded by the Graduate University of Advanced Technology, Kerman, Iran, (No.1.4294).

\section{Ethics approval and consent to participate}

Not applicable.

\section{Consent for publication}

All authors read and approved the final manuscript and gave consent for this publication.

\section{Competing interests}

The authors declare that there are no conflicts of interest in the publication of this manuscript.

\section{Author details}

'Department of Biodiversity, Institute of Science and High Technology and Environmental Sciences, Graduate University of Advanced Technology, Kerman, Iran. ${ }^{2}$ Department of Plant Protection, Faculty of Agriculture, Shahid Bahonar University of Kerman, Kerman 7631818356, Iran.

\section{Received: 12 February 2020 Accepted: 16 April 2020}

Published online: 28 April 2020

\section{References}

Bernal J, Gonzalez D (1997) Reproduction of Diaeretiella rapae on Russian wheat aphid hosts at different temperatures. Entomol Exp Appl 82:159-166

Bezemer TM, Jones TH, Knight KJ (1998) Long-term effects of elevated CO2 and temperature on populations of the peach potato aphid, Myzus persicae and its parasitoid Aphidius matricariae. Oecologia 116:128-135

Boivin G, Hance T, Brodeur J (2012) Aphid parasitoids in biological control. Can J Plant Sci 92(1):1-12

Brown JH, Gillooly JF, Allen AP, Savage VM, West GB (2004) Toward a metabolic theory of ecology. Ecology 85:1771-1789
Byeon YW, Tuda M, Takagi M, Kim JH, Choi MY (2011) Life history parameters and temperature requirements for development of an aphid parasitoid Aphelinus asychis (Hymenoptera: Aphelinidae). Environ Entomol 40:431-440

Carey JR (1993) Applied demography for biologists with special emphasis on insects. Oxford University Press, New York

Costa RR, Moraes JC, DaCosta RR (2010) Feeding behavior of the greenbug Schizaphis graminum on wheat plants treated with imidacloprid and/or silicon. J Appl Entomol 135:115-120

De Farias AMI, Hopper KR (1999) Oviposition behavior of Aphelinus asychis (Hymenoptera: Aphelinidae) and Aphidius matricariae (Hymenoptera: Aphidiidae) and defense behavior of their host Diuraphis noxia (Homoptera: Aphididae). Environ Entomol 28:858-862

Denis D, Pierre J-S, van Baaren J, van Alphen JJM (2011) How temperature and habitat quality affect parasitoid lifetime reproductive success- a simulation study. Ecological Model 222:1604-1613

El-Heneidy AH, El-Hussieni MM, Agamy EA, Adly D (2003) Thermal constants for development of the cereal aphid, Rhopalosiphum padi (Homoptera: Aphididae) and its parasitoid Aphidius matricariae (Hymenoptera: Aphidiidae). Egypt J Biol Pest Co 13:13-18

Farsi A, Kocheili F, Mossadegh MS, Rasekh A (2019) Temperature-dependent life table parameters of Aphidius matricariae (Hym.: Braconidae), an important parasitoid of the currant lettuce aphid, Nasonovia ribiinigri (Hem.: Aphididae). J Entomol Soc Iran 38(4):365-375

Giri MK, Pass BC, Yeargan KV, Parr JC (1982) Behavior, net reproduction, longevity, and mummy-stage survival of Aphidius matricariae (Hym.: Aphidiidae). Entomophaga 27:147-153

Goh HG, Kim JH, Han MW (2001) Application of Aphidius colemani Viereck for control of the aphid in greenhouse. J Asia-Pacific Entomol 4(2):171-174

Jones DB, Giles KL, Berberet RC, Royer TA, Elliott NC, Payton ME (2003) Functional response of an introduced parasitoid and an indigenous parasitoid on greenbug at four temperatures. Environ Entomol32: 425-432.

Liu YH, Tsai JH (2002) Effect of temperature on development, survivorship, and fecundity of Lysiphlebia mirzai (Hymenoptera: Aphidiidae), a parasitoid of Toxoptera citricida (Homoptera: Aphididae). Environ Entomol 31(2):418-424

Maia A, Luiz AJB, Campanhola C (2000) Statistical inference on associated fertility life table parameters using Jackknife technique: computational aspects. J Econ Entomol 93:511-518

Miller JC, Gerth WJ (1994) Temperature-dependent development of Aphidius matricariae (Hymenoptera: Aphidiidae), as a parasitoid of the Russian wheat aphid. Environ Entomol 23(5):1304-1307

Mustață G, Mustață M (2009) The complex of parasitoids limiting the populations of Schizaphis graminum Rond (Homoptera, Aphididae) in some cereal crops from the sea side of the black sea. An Șt Univ Al I Cuza lași s a Biol LV:75-84

Reed HC, Reed DK, Elliot NC (1992) Comparative life table statistics of Diaeretiella rapae and Aphidius matricariae on the Russian wheat aphid. Southwestern Entomol 17(5):307-312

Rohne O (2002) Effect of temperature and host stage on performance of Aphelinus varipes Forster (Hym., Aphelinidae) parasitizing the cotton aphid, Aphis gossypii Glover (Hom.:Aphididae). J Appl Entomol 126:572-576

SAS Institute (1989) SAS/STAT users guide, Version 6, vols. 1 and 2. SAS Institute Inc., Cary, NC.

Schirmer S, Sengonca C, Blaeser P (2008) Influence of abiotic factors on some biological and ecological characteristics of the aphid parasitoid Aphelinus asychis (Hymenoptera: Aphelinidae) parasitizing Aphis gossypii (Sternorrhyncha: Aphididae). Eur J Entomol 105:121-129

Shahrokhi S, Shojai M, Rezvani A, Ostovan H, Abdollahi GA (2004) Investigation on biology and comparison of fertility life table parameters of Aphidius matricariae Haliday on host aphid Schizaphis graminum (Rondani). In: Proceeding of the 16th Iranian Plant Protection Congress, University of Tabriz, Tabriz, Iran, 27 Aug.-1 Sept 2004.

Shijko ES (1989) Rearing and applications of the peach aphid parasites, Aphidius matricariae Haliday (Hymenoptera, Aphidiidae). Acta Entomol Fenn 53:53-56

Tahriri Adabi S, Talebi AA, Fathipour Y, Zamani AA (2010) Life history and demographic parameters of Aphis fabae (Hemiptera: Aphididae) and its parasitoid, Aphidius matricariae (Hymenoptera: Aphidiidae) on four sugar beet cultivars. Acta Entomol Serbica 15(1):61-73

Wang DS, He YR, Zhang W, Nian XG, Lin T, Zhao R (2014) Effects of heat stress on the quality of Trichogrammatoidea bactrae Nagaraja (Hymenoptera: Trichogrammatidae). B Entomol Res 104:543-551

Wang S-Y, Liang N-N, Tang R, Liu Y, Liu T-X (2016) Brief heat stress negatively affects the population fitness and host feeding of Aphelinus asychis 
(Hymenoptera: Aphelinidae) parasitizing Myzus persicae (Hemiptera: Aphididae). Environ Entomol 45(3):719-725

Wang XG, Johnson MW, Daane KM, Nadel H (2009) High summer temperatures affect the survival and reproduction of olive fruit fly (Diptera: Tephritidae). Environ Entomol 38:1496-1504

Wick M (2009) Release of Aphidius matricariae for control of Myzus persicae in glasshouses. EPPO Bull22: 437-444.

Yashima K, Murai T (2013) Development and reproduction of a potential biological control agent, Aphelinus varipes (Hymenoptera: Aphelinidae), at different temperatures. Appl Entomol Zool 48:21-26

Zamani AA, Talebi A, Fathipour Y, Baniameri V (2007) Effect of temperature on life history of Aphidius colemani and Aphidius matricariae (Hymenoptera:

Braconidae), two parasitoids of Aphis gossypii and Myzus persicae (Homoptera: Aphididae). Environ Entomol 36(2):263-271

Zufelato MS, Lourenco AP, Simoes ZLP, Jorge JA, Bitondi MMG (2004)

Phenoloxidase activity in Apis mellifera honey bee pupae, and ecdysteroid dependent expression of the prophenoloxidase mRNA. Insect Biochem Mol Biol 34:1257-1268

\section{Publisher's Note}

Springer Nature remains neutral with regard to jurisdictional claims in published maps and institutional affiliations.

\section{Submit your manuscript to a SpringerOpen ${ }^{\circ}$ journal and benefit from:}

- Convenient online submission

- Rigorous peer review

- Open access: articles freely available online

- High visibility within the field

- Retaining the copyright to your article

Submit your next manuscript at $\boldsymbol{\nabla}$ springeropen.com 